\title{
STUDI KADAR C-REACTIVE PROTEIN (CRP) PADA PENDERITA DIABETES MELITUS TIPE 2
}

\author{
Kalma \\ Jurusan Analis Kesehatan Poltekkes Kemenkes Makassar \\ kalmaanalis@gmail.com
}

\begin{abstract}
ABSTRAK
Diabetes Melitus (DM) termasuk penyakit tidak menular yang banyak menyebabkan kematian di Indonesia. Komplikasi makrovaskular diabetes salah satunya adalah komplikasi kardiovaskular sebagai akibat dari aterosklerosis yang merupakan penyebab utama mortalitas dan morbiditas secara global yang dipengaruhi oleh DM tipe 2. Peningkatan kadar CRP merupakan indikasi yang kuat dan signifikan terhadap risiko terjadinya penyakit kardiovaskular. Tujuan penelitian ini adalah untuk mengetahui kadar CRP pada penderita DM tipe 2. Penelitian ini merupakan penelitian deskriptif dengan teknik pengambilan sampel purposive sampling. Besar sampel pada penelitian ini adalah 20 sampel. Spesimen serum dari sampel penelitian diperiksa dengan metode aglutinasi lateks. Penelitian ini dilaksanakan di laboratorium RSUD Labuang Baji Makassar pada tanggal 8 Maret s/d 12 Mei 2018. Data hasil penelitian dianalisis secara deskriptif. Berdasarkan hasil penelitian yang telah dilaksanakan tentang studi kadar CRP pada penderita DM tipe 2, ternyata 4 sampel negatif dan 16 sampel positif dengan kadar CRP rata-rata 90,80 mg/L. Dengan demikian dapat disimpulkanbahwa terjadi peningkatan kadar CRP pada penderita DM tipe 2 sebagai petanda adanya proses inflamasi akibat komplikasi kronik DM. Dengan demikian disarankan penderita DM tipe 2 melakukan pemeriksaan atau penentuan kadar CRP untuk deteksi dini penyakit kardiovaskular.
\end{abstract}

Kata Kunci : C-Reactive Protein (CRP), Diabetes Melitus (DM)

\section{PENDAHULUAN}

Diabetes Melitus (DM) merupakan suatu kelompok penyakit metabolik dengan karakteristik hiperglikemia yang terjadi karena kelainan sekresi insulin, kelainan kerja insulin atau kedua-duanya.

DM bukan merupakan penyakit menular dan prevalensinya semakin meningkat dari tahun ke tahun. Penyakit tidak menular penyumbang angka kematian terbanyak di Indonesia. Lima tertinggi penyakit tidak menular penyebab kematian di Indonesia adalah stroke, hipertensi, diabetes, kanker, dan penyakit paru obstruktif kronis (Kemenkes RI, 2011). DM yang tidak ditangani dengan tepat akan mengakibatkan berbagai komplikasi kronis diantaranya komplikasi vaskular.

Mortalitas dan morbiditas yang terjadi pada penderita DM tidak secara langsung diakibatkan oleh hiperglikemi, tetapi hal ini berhubungan dengan komplikasi yang terjadi. Komplikasi makrovaskular diabetes salah satunya adalah komplikasi kardiovaskular sebagai akibat dari aterosklerosis 
yangmerupakan penyebab utama mortalitas dan morbiditas secara global yang dipengaruhi oleh DM tipe 2 (Nisa H, 2016).

DM tipe 2 merupakan suatu penyakit metabolik karakteristik yang ditandai dengan peningkatan kadar gula darah, yang terjadi karena penurunan sekresi insulin oleh sel beta pankreas, atau kerja insulin yang tidak sesuai (Depkes, 2008).

Ketidaksesuaian kerja insulin pada penyakit DM ini mengakibatkan glukosa dari pembuluh darah tidak mampu masuk ke jaringan. Keadaan ini menyebabkan sebagian besar glukosa tetap berada dalam sirkulasi darah sehingga terjadi hiperglikemia (Yekti N, 2014).

Beberapa penelitian menunjukkan bahwa kelainan vaskuler terjadi karena adanya low grade chronic inflammation pada endotelium. Keadaan tersebut diperkuat dengan peningkatan marker inflamasi kronis CRP. Ini menunjukkan CRP merupakan marker yang cukup sensitif untuk mendeteksi adanya inflamasi subklinis tersebut yang berhubungan dengan perkembangan dan progress aterosklerosis (Yerizel E dkk, 2015).

Peningkatan kadar CRP merupakan indikasi yang signifikan terhadap risiko terjadinya penyakit kardiovaskular. Jika petanda inflamasi ini dapat terdeteksi lebih awal pada penderita DM tipe 2 maka pemberian terapi dapat segera diberikan sehingga dapat mencegah terjadinya komplikasi kronik.

Ketidaksesuaian kerja insulin pada DM ini mengakibatkan glukosa dari pembuluh darah tidak mampu masuk ke jaringan.

Kasus diabetes yang paling banyak adalah Diabetes Melitus tidak tergantung insulin atau disebut dengan DM tipe 2, yang umumnya mempunyai latar belakang kelainan berupa resistensi insulin. Menurut WHO (2007), diabetes tipe 2 adalah yang terbanyak diantara tipe-tipe DM lainnya. Kalangan profesional menyatakan bahwa diabetes tipe 2 di Indonesia mencapai $85-90 \%$ dari total diabetes. Untuk itu diperlukan upaya pengendalian DM tipe 2, terutama melalui upaya pencegahan dan penanggulangan faktor risiko DM tipe 2 (Aritrina P dkk, 2016).

Diagnosis DM didasarkan atas pemeriksaan kadar glukosa darah dan pemeriksaan HbA1c. Dalam menentukan diagnosis DM harus diperhatikan asal bahan darah yang akan diambil dan cara pemeriksaan yang dipakai. Untuk diagnosis pemeriksaan yang dianjurkan adalah pemeriksaan glukosa dengan cara enzimatik dengan bahan darah plasma vena. Untuk memastikan diagnosis DM, pemeriksaan glukosa darah seyogyanya dilakukan di laboratorium klinik yang terpercaya (yang melakukan program pemantauan kendali mutu secara teratur). Pemeriksaan

HbA1c hendaknya menggunakan metode yang terstandarisasi oleh National Glycohaemoglobin Standarization Program (NGSP). Saat ini belum semua laboratorium di Indonesia memenuhi standard NGSP, sehingga harus hati-hati dalam membuat interpretasi terhadap hasil pemeriksaan HbA1c. Pada kondisi tertentu seperti: anemia, hemoglobinopati, riwayat transfusi darah 2-3 bulan terakhir dan kondisi-kondisi yang memengaruhi umur eritrosit, maka $\mathrm{HbA} 1 \mathrm{c}$ tidak dapat dipakai untuk diagnosis maupun evaluasi diabetes melitus 
Tabel 1.

Tabel. 1 Hasil Pemeriksaan Laboratorium Darah untuk Diagnosis Diabetes Melitus .

\begin{tabular}{|c|c|c|c|}
\hline & HbA1c $(\%)$ & $\begin{array}{c}\text { Glukosa darah } \\
\text { Puasa }(\mathrm{mg} / \mathrm{dl})\end{array}$ & $\begin{array}{c}\text { Glukosa plasma 2 } \\
\text { jam setelah TTGO } \\
(\mathrm{mg} / \mathrm{dl})\end{array}$ \\
\hline Diabetes & $\geq 6,5$ & $\geq 126$ & $\geq 200$ \\
\hline Prediabetes & $5,7-6,4$ & $100-125$ & $140-199$ \\
\hline Normal & $<5,7$ & $<100$ & $<140$ \\
\hline
\end{tabular}

(PERKENI, 2015)

C-Reactive Protein (CRP) adalah salah satu protein fase akut yang terdapat dalam serum normal walaupun dalam jumlah amat kecil. Dalam beberapa keadaan tertentu dengan reaksi radang atau kerusakan jaringan (nekrosis), baik yang disebabkan oleh penyakit infeksi maupun yang bukan oleh karena infesi.

CRP merupakan salah satu petanda inflamasi sistemik akut yang dihasilkan oleh hati dan sering ditemukan banyak penyakit dan berhubungan dengan kejadian DM dan cardiovascular event, bagaimana mekanisme sebenarnya belum diketahui secara pasti (Sylvawani M dkk, 2009).

Terjadinya peningkatan kadar CRP pada penderita DM tipe 2 disebabkan oleh respons inflamasi yang timbul akibat komplikasi dari DM.Beberapa penelitian menunjukkan bahwa kelainan vaskuler terjadi karena adanya lowgrade chronic inflammation pada endotelium. Keadaan tersebut diperkuat dengan peningkatan beberapa marker inflamasi kronis seperti IL-6 dan CRP. Ini menunjukkan bahwa CRP merupakan marker yang cukup sensitif untuk mendeteksi adanya inflamasi subklinis tersebut(Yerizel E dkk, 2015).

Pada penelitian epidemiologi prospektif, nilai CRP dapat stroke, penyakit arteri perifer dan kematian jantung mendadak, juga dapat memperkirakan risiko iskemia berulang dan kematian pada penderita angina yang stabil dan tidak stabil yang menjalani angioplasti perkutan. Selain untuk prediksi kelainan kardiovaskular, sekarang nilai CRPjuga digunakan untuk memprediksi DM tipe 2 pada beberapa penelitian prospektif yang telah dilakukan oleh Barzilay, Pradhan, Freeman (Sylvawani M, 2009).

CRP merupakan salah satu biomarker yang berperan sebagai protein fase akut pada proses inflamasi. Jika pada pasien penyakit jantung koroner biomarker ini dapat terdeteksi lebih awal maka pemberian terapi dapat segera diberikan sehingga dapat mencegah kerusakan otot jantung lebih lanjut (Setiawan I dkk, 2011).

Dalam waktu yang relatif singkat (6-8 jam) setelah terjadinya reaksi radang akut/kerusakan jaringan, sintesis, dan sekresi dari CRP meningkat dengan tajam, dan hanya dalam waktu 24-48 jam telah mencapai nilai puncaknya. Kadar dari CRP akan menurun dengan tajam pula bila proses inflamasi/kerusakan jaringan telah mereda. Dalam waktu sekitar 24-48 jam telah dicapai nilai normalnya kembali (Handojo I, 2004)

Fungsi dan peranan CRP di dalam tubuh (in vivo) belum diketahui 
seluruhnya, banyak hal yang masih merupakan hipotesis. Meskipun CRP bukan sesuatu antibodi, tetapi CRP mempunyai berbagai fungsi biologis yang menunjukkan peranannya pada proses keradangan, dan mekanisme daya tahan tubuh terhadap infeksi (Handojo I, 2004).

Pemeriksaan C-Reactive Protein (CRP) pada penelitian ini mengunakan Metode Aglutinasi Lateks. Prinsip pemeriksaan CRP dengan metode Aglutinasi lateks adalah antibodi yang disalutkan pada partikel untuk menentukan adanya antigen di dalam spesimen serum. Pada pengujian ini dilakukan dengan menambahkan suspensi partikel lateks yang dilapisi dengan antibodi anti-human CRP kepada spesimen serum yang diuji. Dengan adanya aglutinasi yang terlihat mengindikasikan adanya peningkatan kadar CRP ke tingkat klinis yang signifikan (CRP Latex Test Kit, 2013).

Karakteristik kinerja reagensia yang digunakan : sensitivitas analitik: 6 $\mathrm{mg} / \mathrm{L} \quad(5-10) \quad \mathrm{mg} / \mathrm{L}, \quad$ sensitivitas diagnostik: $95,6 \%, \quad$ spesifisitas diagnostik: $96,2 \%$. Titer dinyatakan sebagai hasil perkalian dari pengenceran tertinggi yang menunjukkan aglutinasi dengan 6 $\mathrm{mg} / \mathrm{L}$.

Interpretasi hasil

Terjadinya aglutinasi menunjukkan titer CRP pada sampel $>6 \mathrm{mg} / \mathrm{L}$. Kurangnya aglutinasi menunjukkan tingkat titer CRP $<6 \mathrm{mg} / \mathrm{L}$ pada sampel. CRP lateks telah distandarisasi untuk mendeteksi titer. CRP serum $\geq 6 \mathrm{mg} / \mathrm{L}$, yang dianggap sebagai konsentrasi klinis terendah. Pemantauan titer CRP sering digunakan untuk menilai aktivitas penyakit dan pemantauan pengobatan. Penentuan CRP dianggap lebih penting daripada indikator penyakit inflamasi lainnya. Nilai sedimentasi eritrosit (ESR) misalnya, dapat meningkat sebagai akibat dari kondisi non inflamasi. Dalam keadaan ini, penyakit inflamasi dapat dikesampingkan jika CRP tidak ada.

\section{METODE}

Penelitian ini termasuk jenis penelitian deskriptif untuk mengetahui titer atau kadar CRP pada penderita DM tipe 2.

Sampel pada penelitian ini adalah penderita DM tipe 2 di RSUD Labuang Baji Makassar. Sampel diambil dengan teknik purposive sampling.

Kriteria inklusi antara lain : Penderita DM dengan kadar glukosa darah puasa $\geq 126 \mathrm{mg} / \mathrm{dL}$, telah menderita DM selama 5-10 tahun, bersedia menandatangani informed consent. Kriteria eksklusi yaitu penderita dengan Rheumatoid Arthritis, penderita Systemic Lupus Erythematosus, dan penderita dengan tanda-tanda infeksi secara klinik.

Bahan penelitian yang digunakan dalam penelitian ini adalah serum, reagen CRP lateks (sensitivitas analitik $6 \mathrm{mg} / \mathrm{L}$ ), serum kontrol positif, serum kontrol negatif dan $\mathrm{NaCl}$ 0,9\%

Instrumen yang digunakan dalam penelitian ini adalah spoit, tourniqet, kapas alkohol, handscoon, sentrifus, slide tes, klinipet,yellow tip, blue tip, pengaduk, rotator.

\section{Prosedur pemeriksaan spesimen dari sampel Penelitian}

Pra Analitik antara lain: mempersiapakan instrumen, bahan, pengambilan dan penanganan spesimen darah vena sampai diperoleh serum.

Tahapan Analitik dilakukan pemeriksaan kualitatif dan pemeriksaan kuantitatif : 
Pemeriksaan Kualitatif :

Reagen lateks CRP dihomogenkan dengan hati-hati, dipipet ke atas lingkaran slide sampel serum sebanyak 1 tetes $(50 \mu \mathrm{L})$, kontrol positif $(\mathrm{CP})$ dan kontrol negatif $(\mathrm{CN})$, kemudian ditambahkan 1 tetes reagen lateks (antigen CRP) masing-masing ke atas lingkaran tersebut. Dihomogenkan dengan cara memutar pada rotator dengan kecepatan $100 \mathrm{rpm}$ selama 2 menit. Setelah itu, hasil dibaca di bawah sinar terang. Aglutinasi yang terjadi menunjukkan CRP positif ( CRP dalam spesimen $\geq 6 \mathrm{mg} / \mathrm{L}$ )

Pemeriksaan Semi Kuantitatif :

Serum dengan metode kualitatif positif, dilanjutkan dengan penentuan titer CRP dalam serum. Yaitu dengan melakukan pengenceran sampel secara seri, dengan cara dipipet sebanyak 50 $\mu \mathrm{L} \mathrm{NaCl}$ 0,9\% ke atas 6 lingkaran slide. Setelah itu, dipipet $50 \mu \mathrm{L}$ serum ke atas lingkaran I (pengenceran 2 kali), dihomogenkan. Dipipet suspensi dari lingkaran I sebanyak $50 \mu \mathrm{L}$ ke atas lingkaran II (pengenceran 4 kali), sampai ke slide $\mathrm{V}$ (pengenceran 32 kali). Dipipet sebanyak $50 \mu \mathrm{L}$, ke lingkaran VI (untuk stok), jika masih menunjukkan hasil positif pada lingkaran V. Setelah itu,ditambahkan ke atas masing-masing lingkaran reagen lateks CRP sebanyak 1 tetes. Dihomogenkan dengan cara memutar pada rotator dengan kecepatan $100 \mathrm{rpm}$ selama 2 menit. Setelah itu, hasil dibaca di bawah sinar terang. Pengenceran tertinggi yang masih poditif (tampak aglutinasi) dikalikan dengan $6 \mathrm{mg} / \mathrm{L}$ menunjukkan titer CRP dalam spesimen serum yang diperiksa.

\section{HASIL}

Hasil pemeriksaan glukosa darah puasa dan CRP pada spesimen serum penderita DM tipe 2 diperoleh hasil sebagaimana tercantum pada tabel 2 .

Tabel 2. Hasil pemeriksaan glukosa darah CRP pada spesimen serum penderita DM tipe 2 :

\begin{tabular}{|c|c|c|c|c|}
\hline \multirow[b]{2}{*}{ No. } & \multirow{2}{*}{$\begin{array}{c}\text { Kode } \\
\text { Sampel }\end{array}$} & \multicolumn{2}{|c|}{ Hasil Pemeriksaan } & \multirow[b]{2}{*}{ Ket } \\
\hline & & $\begin{array}{c}\text { Glukosa Darah Puasa } \\
(\mathrm{mg} / \mathrm{dl})\end{array}$ & $\begin{array}{c}\text { CRP } \\
(\mathrm{mg} / \mathrm{L})\end{array}$ & \\
\hline 1 & A & 132 & 192 & \\
\hline 2 & B & 136 & 96 & \\
\hline 3 & $\mathrm{C}$ & 151 & 96 & \\
\hline 4 & $\mathrm{D}$ & 173 & 192 & \\
\hline 5 & $\mathrm{E}$ & 136 & Negatif & \\
\hline 6 & $\mathrm{~F}$ & 160 & 96 & \\
\hline 7 & G & 152 & Negatif & \\
\hline 8 & $\mathrm{H}$ & 260 & 12 & \\
\hline 9 & I & 243 & 24 & \\
\hline 10 & $\mathrm{~J}$ & 326 & 12 & \\
\hline 11 & $\mathrm{~K}$ & 318 & 192 & \\
\hline 12 & $\mathrm{~L}$ & 172 & 48 & \\
\hline 13 & $\mathrm{M}$ & 133 & Negatif & \\
\hline 14 & $\mathrm{~N}$ & 136 & Negatif & \\
\hline 15 & $\mathrm{O}$ & 380 & 192 & \\
\hline
\end{tabular}




\begin{tabular}{|c|c|c|c|}
\hline 16 & $\mathrm{P}$ & 279 & 24 \\
\hline 17 & $\mathrm{Q}$ & 132 & 48 \\
\hline 18 & $\mathrm{R}$ & 202 & 192 \\
\hline 19 & $\mathrm{~S}$ & 130 & 192 \\
\hline 20 & $\mathrm{~T}$ & 140 & 192 \\
\hline
\end{tabular}

Sumber: Data Primer 2018

Tabel 3. Hasil pemeriksaan CRP pada spesimen serum penderita DM tipe 2 .

\begin{tabular}{|c|c|c|c|c|c|}
\hline \multicolumn{8}{|c|}{ Hasil pemeriksaan CRP } \\
\hline \multicolumn{2}{|c|}{ Positif } & \multicolumn{2}{c|}{ Negatif } & \multicolumn{2}{c|}{ Jumlah } \\
\hline $\mathrm{n}$ & $\%$ & $\mathrm{n}$ & $\%$ & $\mathrm{n}$ & $\%$ \\
\hline 16 & 80 & 4 & 20 & 20 & 100 \\
\hline
\end{tabular}

Hasil pemeriksaan CRP pada 20 spesimen serum penderita DM tipe 2 yang diperiksa, diperoleh $16(80 \%)$ CRP positif, dan $4(20 \%)$ CRP negatif.

Tabel 4. Kadar rata-rata glukosa darah puasa dan kadar CRP pada spesimen serum penderita DM tipe 2.

\begin{tabular}{|l|c|}
\hline \multicolumn{1}{|c|}{ Jenis Pemeriksaan } & Rata-Rata $(\mathrm{mg} / \mathrm{dL}, \mathrm{mg} / \mathrm{L})$ \\
\hline Glukosa Darah Puasa & 194,55 \\
\hline C-Reaktive Protein (CRP) & 90,80 \\
\hline
\end{tabular}

Kadar glukosa darah puasa pada spesimen serum penderita DM tipe 2 rata-rata $=194,55 \mathrm{mg} / \mathrm{dL}$ dan spesimen serum penderita DM tipe 2 yang CRP positif kadarnya ratarata $=90,80 \mathrm{mg} / \mathrm{L}$.

\section{PEMBAHASAN}

Pada hasil penelitian yang telah dideskripsikan sebelumnya, diperoleh bahwa dari 20 subjek yang memiliki CRP positif sebanyak 16 orang $(80 \%)$ dan yang negatif sebanyak 4 orang (20\%). Pada penderita DM tipe 2, terjadi peningkatan kadar CRP ratarata 90,80 mg/L. Jumlah kadar CRP pada subjek yang memiliki CRP negatif adalah $\leq 5 \mathrm{mg} / \mathrm{L}$.Pada penderita DM tipe 2 terjadi peningkatan kadar glukosa darah yang menyebabkan terjadinya kondisi hiperglikemia secara kronis. Terjadinya peningkatan kadar CRP pada penderita DM tipe 2 disebabkan oleh respon inflamasi yang timbul akibat komplikasi dari DM. Hal ini diawali oleh keadaan hiperglikemia intrasel menyebabkan kerusakan mitokondria pada DM tipe 2 yang mengakibatkan terjadinya peningkatan ROS dan stres oksidatif sehingga radikal bebas meningkat dalam tubuh. ROS adalah radikal bebas yang terbentuk ketika $\mathrm{O}_{2}$ menerima elektron bebas. Peningkatan radikal bebas ini akan menyebabkan kerusakan makrovaskular dan mikrovaskular.Mekanisme kerusakan jaringan tubuh pada DM adalah melalui jalur biokimia seperti jalur reduktase aldosa, jalur stres oksidatif sitoplasmik, jalur pleiotropik PKC danterbentuknya species glikosilasi 
lanjut intraseluler.Peningkatan sintesis DAG menyebabkan ekspresi PKC dalam sel juga meningkat yang pada akhirnya akan mengubah berbagai macam ekspresi gen yang secara keseluruhan merusak pembuluh darah. Peningkatan aktivasi PKC mengakibatkan peningkatan NF-kB yang merupakan faktor transkripsi untuk mengaktifkan gen-gen proinflamasi dalam pembuluh darah yang disebut proinflammatory gene expression. Sehingga aktivasi dari NF$\mathrm{kB}$ akan membuat jumlah sitokin proinflamasi meningkat. Dengan meningkatnya jumlah sitokin proinflamasi dalam darah antara lain IL-6 dan TNF- $\alpha$, maka hepar akan merespon dengan mensintesis CRP. Hal ini memperkuat bahwa pada pasien DM tipe 2 terjadi peningkatan kadar CRP.

Berdasarkan penelitian Yerizel E dkk (2015) juga menyatakan bahwa terjadinya peningkatan kadar CRP pada penderita DM tipe 2 disebabkan oleh respon inflamasi yang timbul akibat komplikasi dari DM.

Menurut Shahab A (2010) bahwa diabetes memberikan pengaruh terhadap terjadinya komplikasi kronik melalui adanya perubahan pada sistem vaskular, disebabkan karena kontrol glukosa darah yang buruk dalam waktu yang lama. Selain itu, menurut Waspadji (2010) perubahan dasar atau disfungsi yang terjadi pada endotel pembuluh darah, sel otot polos pembuluh darah maupun sel mesangial ginjal semuanya menyebabkan perubahan pada pertumbuhan dan kesintasan sel, yang kemudian akan menyebabkan terjadinya komplikasi vaskular diabetes.

Haffner dkk dalam Shahab A (2010) membuktikan bahwa aterosklerosis pada penderita DM mulai terjadi sebelum onset klinis DM. Studi epidemiologi juga menunjukkan terjadinya peningkatan risiko payah jantung pada penderita DM tipe 2 dibandingkan populasi non-DM, yang ternyata disebabkan oleh karena kontrol glukosa darah yang buruk dalam waktu yang lama. Salah satu penyebab terjadinya lesi aterosklerosis pada penderita DM adalah hiperglikemia, resistensi insulin \& hiperinsulinemia dislipidemia dan inflamasi. Terjadinya plak aterosklerosis pada daerah subintimal pembuluh darah dan kemudian sindrom koroner akut. Patogenesis kelainan vaskular pada DM meliputi terjadinya matabolik dan hormonal. Pertumbuhan sel otot maupun sel mesangial keduanya distimulasi oleh sitokin.

Jaringan kardiovaskular, demikian juga jaringan lain yang rentan terhadap terjadinya komplikasi kronik diabates (jaringan saraf, sel endotel pembuluh darah dan sel retina serta lensa) mempunyai kemampuan untuk memasukkan glukosa dari lingkungan sekitar ke dalam sel tanpa memerlukan insulin (insulin independent), agar dengan demikian jaringan yang sangat penting tersebut akan diyakinkan akan mendapat cukup pasokan glukosa sebelum glukosa tersebut dipakai untuk energi di otot maupun untuk kemudian disimpan sebagai cadangan lemak. Tetapi pada keadaan hiperglikemia kronik, tidak cukup terjadi downregulation dari sistem transportasi glukosa yang noninsulin dependentini, sehingga sel akan kebanjiran masuknya glukosa, suatu keadaan yang disebut sebagai hiperglisolia.

Hiperglisolia kronik akan mengubah homeostasis biokimia sel tersebut yang kemudian berpotensi 
untuk terjadinya perubahan dasar terbentuknya komplikasi kronik diabetes, yang meliputi jalur biokimia seperti jalur reduktase aldosa, jalur stres oksidatif sitoplasmik, jalur pleiotropik protein kinase $\mathrm{C}$ dan terbentuknya species glikosilasi lanjut intraselular. Dari berbagai mekanisme dasar tersebut semuanya akan menyebabkan terjadinya disfungsi endotel, mengganggu dan mengubah sifat berbagai protein penting dan kemudian akan memacu terbentuknya sitokin proinflamasi serta faktor pertumbuhan. Sehingga prototipe petanda adanya inflamasi yaitu CRP akan meningkat seiring dengan meningkatnya A1c. Jelas bahwa proses inflamasi penting pada terjadinya komplikasi kronik DM.

tahun terakhir, terbukti bahwa inflamasi tidak hanya menimbulkan komplikasi sindrom koroner akut, tetapi juga merupakan penyebab utama dalam proses terjadinya dan progresivitas aterosklerosis. Berbagai pertanda inflamasi telah ditemukan di dalam lesi aterosklerosis, antara lain sitokin dan growth factors yang dilepaskan oleh makrofag dan $T$ cells. Sitokin akan meningkatkan sintesisPAF, merangsang lipolisis, ekspresi molekul-molekul adhesi dan upregulasi sintesis serta ekspresi aktivitas prokoagulan di dalam sel-sel endotel. Jadi sitokin memainkan peran penting tidak hanya di dalam proses awal terbentuknya lesi aterosklerosis, melainkan juga progresivitasnya. Pelepasan sitokin lebih banyak terjadi pada pasien DM, karena peningkatan dari berbagai proses yang mengaktivasi makrofag (dan pelepasan sitokin), antara lain oksidasi dan glikooksidasi protein dan lipid. Di samping itu terjadi pula peningkatan pembentukan kompleks imun yang mengandung modified lipoprotein. Tingginya konsentrasi kompleks imun yang mengandung modified $L D L$, akan meningkatkan risiko komplikasi makrovaskular pada pasien DM baik DM tipe 1 maupun tipe 2. Kompleks imun ini tidak hanya merangsang pelepasan sejumlah besar sitokin tetapi juga merangsang ekspresi dan pelepasan matrix metalloproteinase-1 tanpa merangsang sintesis inhibitornya. Aktivasi makrofag oleh kompleks imun tersebut akan merangsang pelepasan TNF- $\alpha$, yang menyebabkan up regulasi sintesis CRP.

Pada beberapa penelitian telah ditemukan CRP dengan konsentrasi yang cukup tinggi pada pasien dengan resistensi insulin. Peningkatan konsentrasi kompleks imun pada pasien DM tidak hanya menyebabkan timbulnya aterosklerosis dan progresivitasnya, melainkan juga berperan dalam proses ruptur plak aterosklerotik dan komplikasi Jantung Koroner selanjutnya. Kandungan makrofag di dalam lesi aterosklerosis pada pasien DM mengalami peningkatan, sebagai akibat dari peningkatan rekrutmen makrofag di dalam dinding pembuluh darah karena pengaruh tingginya konsentrasi sitokin. Peningkatan oxidized $L D L$ pada pasien DM akan meningkatkan aktivasi sel $\mathrm{T}$ yang akan meningkatkan pelepasan IFN- $\gamma$. Pelepasan IFN- $\gamma$ akan menyebabkan gangguan homeostasis sel-sel pembuluh darah. Aktivasi sel $\mathrm{T}$ juga akan menghambat proliferasi sel-sel otot polos pembuluh darah dan biosintesis kolagen, yang akan menimbulkan vulnerable plaque, sehingga menimbulkan komplikasi Sindrom Koroner Akut. 
Sehingga apabila dihubungkan dengan penelitian ini, maka dapat disimpulkan bahwa kadar CRP pada penderita DM tipe 2 akan meningkat yaitu $\geq 6 \mathrm{mg} / \mathrm{L}$ sebagai akibat respon inflamasi yang timbul akibat komplikasi dari DM yang akan disebabkan oleh keadaan hiperglikemia secara kronis. Pada penderita DM tipe 2 diawali oleh keadaan hiperglikemia yang disebabkan oleh insensitivitas seluler terhadap insulin. Selain itu, terjadi defek sekresi insulin akibat ketidakmampuan pankreas untuk menghasilkan insulin yang cukup untuk mempertahankan glukosa plasma yang normal. Hiperglikemia kronik pada DM memberikan pengaruh terhadap terjadinya komplikasi kronik berhubungan dengan adanya perubahan dasar atau disfungsi yang terjadi pada sistem vaskular, terutama pada endotel pembuluh darah, sel otot polos pembuluh darah maupun mesangial ginjal. Semuanya menyebabkan perubahan pada pertumbuhan dan kesintasan sel kemudian menyebabkan terjadinya komplikasi vaskular diabetes yang mengarah ke proses aterosklerosis.

Terbentuknya komplikasi

kronik DM melalui berbagai mekanisme dasar meliputi beberapa jalur biokimia seperti jalur reduktase aldosa, jalur stres oksidatif sitoplasmik, jalur pleiotropik protein kinase $\mathrm{C}$ dan terbentuknya species glikosilasi lanjut intraselular. Kemudian menyebabkan terjadinya disfungsi endotel, mengganggu dan mengubah sifat berbagai protein penting dan kemudian akan meningkatkan terbentuknya faktor pertumbuhan dan sitokin proinflamasi di dalam darah antara lain IL-6 dan
TNF- $\alpha$ yang akan memacu hepar memproduksi CRP. Sehingga kadar CRP pada penderita DM tipe 2 akan meningkat. CRP merupakan sebagai petanda fase akut inflamasi yang berhubungan dengan kerusakan jaringan. Hal ini memperkuat bahwa keadaan hiperglikemia kronis dapatmenyebabkan kerusakan hampir seluruh jaringan tubuh, terutama pada jaringan yang dipengaruhi insulin dan akan memengaruhi respon inflamasi kronis seperti CRP.Proses kerusakan umumnya berawal dari adanya kelainan pembuluh darah mikro dan makrovaskular. Komplikasi makrovaskular biasanya sebagai akibat dari aterosklerosis. Salah satu penyulit makrovaskular pada DM adalah penyakit jantung koroner yang bermanifestasi sebagai aterosklerosis dini yang dapat mengenai organ-organ vital (jantung dan otak).Penyebab terjadinya aterosklerosis pada DM tipe 2 bersifat multifaktorial, salah satunya adalah melibatkan interaksi kompleks dari berbagai keadaan seperti hiperglikemia, dislipidemia,resistensi insulin \&hiperinsulinemia, dislipidemia, dan inflamasi. Aterosklerosis adalah suatu proses yang mendasari terbentuknya penyempitan pembuluh darah setempat oleh plak aterosklerotik, yang mengakibatkan terhambatnya aliran darah. Terjadinya plak aterosklerosis pada daerah subintimal pembuluh darah dan kemudian berlanjut pada terbentuknya penyumbatan pembuluh darah dan kemudian Sindrom Koroner Akut.Jika pada penderita penyakit jantung koroner,peningkatan kadar CRP dapat terdeteksi lebih awal maka pemberian terapi dapat segera diberikan sehingga dapat mencegah kerusakan otot jantung lebih lanjut. 
Ada beberapa faktor yang dapat meningkatkan kadar CRP yang tidak diikutsertakan pada penelitian ini yaitu infeksi, peradangan, trauma dan luka bakar. Selain penyakit DM, ada penyakit-penyakit lain dengan kadar CRP tinggi yaitu Active Juvenille Arthritis, Sindrom Vaskulitis, Arthritis Reumatoid, Demam Rematik, Infark Miokard, Penyakit Crohn (Kolitis Granulomatosa), Amiloidosis Sekunder, dan infeksi-infeksi bakteri.

Obat-obatan yang dapat menghambat produksi dari CRP hanya colchicine dan statin, sedangkan obat imunosupresif (corticosteroid, dan lain sebagainya) atau obat anti radang (NSAID) tidak dapat menghambat sekresinya.

Pada kelompok penderita dengan risiko aterosklerosis (penyakit jantung koroner, dan stroke), proses peradangan yang terjadi bersifat menahun, dan pada umumnya tanpa gejala, sehingga dalam keadaan ini kadar CRP-nya juga relatif rendah. Seperti yang ditunjukkan pada hasil pemeriksaan CRP pada penderita DM tipe 2 dengan komplikasi penyakit jantung koroner (PJK) menunjukkan hasil negatif atau kadar CRP $<6 \mathrm{mg} / \mathrm{L}$. Dalam hal tersebut, untuk mengetahui adanya risiko aterosklerosis pada seseorang yang dicurigai, diperlukan suatu sarana laboratoris yang sensitif, yaitu yang dapat mengukur kadar CRP sampai < 0,2-0,3 mg/L yang disebut hs-CRP.

Selain itu, sampel dengan konsentrasi CRP tinggi dapat memberikan hasil negatif. Sehinggadiperlukan pemeriksaan ulang dengan pengenceran, untuk menghindari adanya fenomena zona pasca atau post-zone yang disebabkan oleh kelebihan antigen.Namun hal ini menjadi kelemahan penelitian ini, dimana tanpa dilakukan pengenceran dan pemeriksaan ulang terhadap sampel yang negatif. Sehingga hasil tidak dapat ditentukan sebagai negatif semu atau negatif sejati. Maka disarankan dalam pemeriksaan CRP metode aglutinasi lateks apabila hasil negatif, harus diulangi dengan pengenceran yaitu dengan menggunakan sampel $20 \mu \mathrm{l}$ untuk menghindarkan adanya fenomena post-zone akibat kelebihan antigen.

\section{Kesimpulan}

Berdasarkan hasil dan pembahasan penelitian yang telah dilaksanakan tentang studi kadar CRP pada penderita DM tipe 2 yang berjumlah 20 sampel, ternyata 4 sampel negatif dan 16 sampel positif dengan kadar CRP rata-rata 90,80 mg/L. Dengan demikian dapat disimpulkan bahwa terjadi peningkatan kadar CRP pada penderita DM tipe 2 sebagai petanda adanya proses inflamasi akibat komplikasi kronik DM.

\section{SARAN}

1. Disarankan penderita DM tipe 2 melakukan pemeriksaan atau penentuan kadar CRP untuk deteksi dini penyakit kardiovaskular.

2. Kelemahan atau kekurangan penelitian ini antara lain : detektabilitas atau sensitivitas analitik reagensia yang digunakan relatif rendah atau kurang yaitu 6 $\mathrm{mg} / \mathrm{L}$. Disamping itu sampel penelitian yang relatif kurang.

\section{DAFTAR PUSTAKA}

Aritrina P, Marzuki A, Mangerangi F, 2016. Analisis Kadar Low Density Lipoprotein sebagai Faktor Risiko Komplikasi pada Pasien Diabetes Melitus Tipe 2. Jurnal Universitas 
Halu Oleo, 4, 291. Diakses 11 Januari 2018, dari http://ojs.uho.a c.id

Baratawidjaja KG, Renggaris I, 2010. Imunologi Dasar. Jakarta: Fakultas Kedokteran Universitas Indonesia.

Brown CT, 2014. Patofisiologi Konsep Klinis Proses-Proses Penyakit. Jakarta: Penerbit Buku Kedokteran EGC.

Candra B, 2008. Metodologi Penelitian Kesehatan. Jakarta: Penerbit Buku Kedokteran EGC.

Corwin EJ, 2009. Buku Saku Patofisiologi. Jakarta: Penerbit Buku Kedokteran EGC.

Dalimunte AR, 2008. Gambaran Kadar Glukosa Darah Puasa pada Kelompok yang Berisiko Tinggi Diabetes Melitus Tipe 2 di Kota Medan.Diakses 28 Desember 2017,dari http://repository.usu.ac.id

Departemen Kesehatan RI, 2008.Pedoman Pengendalian Diabetes Melitus dan Penyakit Metabolik. Diakses 20 Januari 2018, dari http://perpu stakaan.depkes.go.id

Fatimah RN, 2015. Diabetes Melitus Tipe 2. Journal Majority, 4, 94. Diakses 11 Desember 2017, dari http://juke.kedokteran.unila.ac.id

Fitrania F,2008. Gambaran Epidemiologi Hiperglikemia dan Faktor-Faktor yang Mempengaruhi pada Jamaah Majelis Dzikir SBY Nurussalam Wilayah Jakarta tahun 2008. Diakses 20 Desember 2017 dari lib.ui.ac.id

Gandasoebrata R, 2009. Penuntun Laboratorium Klinik. Jakarta: Dian Rakyat.
Guyton AC, 2013. Fisiologi Manusia dan Mekanisme Penyakit. Jakarta: Penerbit Buku Kedokteran EGC.

Handojo I, 2003. Pengantar Imunoasai Dasar. Surabaya: Airlangga University Press.

Handojo I, 2004. Imunoasai Terapan pada Beberapa Penyakit Infeksi. Surabaya: Pusat Penerbitan dan Percetakan Unair (AUP).

Hidana R, Ariyanto, 2014. Gambaran kadar CRP pada Keturunan Diabetes Melitus Tipe 2 di Puskesmas Sukaraja.Jurnal Kesehatan Bakti Tunas Husada, 12, 103-104. Diakses 8 Desember 2017, dari http://ejurnal.stikesbth.ac.id

Anonim, 2017. Huma Tex CRP Latex Agglutination Slide Test. Jerman: Human.

Kementerian Kesehatan RI, 2013. Profil Kesehatan Indonesia 2010. Jakarta: Kemenkes RI.

Kowalak JP, Welsh W, Mayer Brenna, 2012. Buku Ajar Patofisiologi. Jakarta: Penerbit Buku Kedokteran EGC.

Kresno SB, 2013. Imunulogi : Diagnosis dan Prosedur Laboratorium. Jakarta: Badan Penerbit Fakultas Kedokteran Universitas Indonesia Jakarta.

Mitchell RN, Cotran RS, 2007. Buku Ajar Patologi Robbins. Jakarta: Penerbit Buku Kedokteran EGC.

Nisa H, 2016. Peran C-Reactive Protein untuk Menimbulkan Risiko Penyakit. JMI, 13, 18. Diakses 20 Oktober 2017, dari http://repository.uinjkt.ac.id

Perkumpulan Endokrinologi Indonesia, 2015. Konsensus dan Pencegahan Diabetes Melitus Tipe 2 di Indonesia. Jakarta: Pengurus Besar Perkumpulan Endokrinologi Indonesia. Diakses 
14 Desember 2017, dari pbperkeni.or.id

Purnamasari D, 2010. Buku Ajar Ilmu Penyakit Dalam: Diagnosis dan Klasifikasi Diabetes Melitus. Jakarta: Interna Publishing Pusat Penerbitan Ilmu Penyakit Dalam

Riyanto A, 2011. Aplikasi Metodologi Penelitian Kesehatan. Yogyakarta: Nuha Medika.

Schoen FJ, Cotran RS, 2007. Buku Ajar Patologi Robbins. Jakarta: Penerbit Buku Kedokteran EGC.

Setiawan I, Wardhani V, Sargono D, 2011. Akurasi Fibrinogen dan HsCRP sebagai Biomarker pada Sindrom Koroner Akut. Jurnal Kedokteran Brawijaya, 26, 234237. Diakses 28 Desember 2017, dari www.jkb.ub.ac.id

Shahab A, 2010. Buku Ajar Ilmu Penyakit Dalam: Komplikasi Kronik Diabetes Melitus Penyakit Jantung Koroner. Jakarta: Interna Publishing Pusat Penerbitan Ilmu Penyakit Dalam

Subowo, 2014. Imunologi. Jakarta: CV Sagung Seto.

Suyono S, 2010. Buku Ajar Ilmu Penyakit Dalam: Diabetes Melitus di Indonesia. Jakarta: Interna Publishing Pusat Penerbitan Ilmu Penyakit Dalam.
Sylvawani M, Lindarto D, 2009. Perbandingan Kadar C-Reactive Protein pada Keturunan Diabetes Melitus Tipe 2.Diakses 8 Desember 2017, dari http://repository.usu.ac.id

Waspadji S, 2010. Buku Ajar Ilmu Penyakit Dalam: Komplikasi Kronik Diabetes Melitus. Jakarta: Interna Publishing Pusat Penerbitan Ilmu Penyakit Dalam.

Wikipedia Ensiklopedia Bebas, 2017. Protein C-Reaktif. Diakses 21 Januari 2018, dari https://id.wikipedia.org

Yekti N, Rochmah YS, Mujayanto R, 2014. Analisa Profil Kadar CReactive Protein pada Status Kesehatan Periodontal Pasien Diabetes Melitus Tipe 2. Odonto Dental Journal, 1, 19-23. Diakses 28 Desember 2017, dari http://jurnal.unissula.ac.id

Yerizel E, Hendra P, Edward Z, Bachtiar H, 2015. Pengaruh Hiperglikemia terhadap High Sensitive C-Reactive Protein (HsCRP) pada Penderita Diabetes Melitus Tipe 2. Prosiding Seminar Ilmiah PBBMI, 51-55. Diakses 28 Desember 2017, dari http://libmed.ugm.ac.id 